\title{
Gill dimensions in near-term embryos of Amazonian freshwater stingrays (Elasmobranchii: Potamotrygonidae) and their relationship to the lifestyle and habitat of neonatal pups
}

\author{
Wallice Paxiúba Duncan ${ }^{1}$, Maria Isabel da Silva² and Marisa Narciso Fernandes ${ }^{3}$
}

This comparative study of gill morphometrics in near-term embryos of freshwater stingray potamotrygonids examines gill dimensions in relation to neonatal lifestyle and habitat. In embryos of the potamotrygonids Paratrygon aiereba, Plesiotrygon iwamae, Potamotrygon motoro, Potamotrygon orbignyi, and cururu ray Potamotrygon sp. the number and length of filaments, total gill surface area, mass-specific surface area, water-blood diffusion distance, and anatomical diffusion factor were analysed. In all potamotrygonids, the $3^{\text {rd }}$ branchial arch possessed a larger respiratory surface than the other gill arches. Larger embryos had more gill surface area and large spiracles, which are necessary to maintain the high oxygen uptake needed due to their larger body size. However, the higher mass-specific gill surface area observed in near-term embryos may be advantageous because neonates can use hypoxic environments as refuges against predators, as well as catch small prey that inhabit the same environment. As expected from their benthic mode of life, freshwater stingrays are sluggish animals compared to pelagic fishes. However, based on gill respiratory morphometry (such as gill area, mass-specific gill area, the water-blood diffusion barrier, anatomical diffusion factor, and relative opening of the spiracle), subtypes of lifestyles can be observed corresponding to: active, intermediate, and sluggish species according to Gray's scale.

Este estudo realizado com embriões a termo de arraias de água doce (Potamotrygonidae) compara e analisa as dimensões branquiais em relação ao estilo de vida e habitat dos neonatos. Nos embriões de Paratrygon aiereba, Plesiotrygon iwamae, Potamotrygon motoro, Potamotrygon orbignyi e Potamotrygon sp. (arraia cururu) foram analisados número e comprimento dos filamentos, área branquial, área superficial branquial massa-específica, barreira de difusão água-sangue e fator de difusão anatômico. Em todos os potamotrigonídeos estudados, o $3^{\circ}$ arco branquial possui uma superfície respiratória maior que os demais arcos. Embriões de espécies de maior porte possuem grandes espiráculos e maior área de superfície branquial. Isso ajuda a manter a taxa de absorção de oxigênio proporcional ao requerimento do animal. No entanto, a grande área de superfície branquial massa-específica observadas nos embriões a termo pode ser vantajosa, pois os neonatos podem usar ambientes hipóxicos como refúgios contra predadores, bem como capturar pequenas presas que habitam o mesmo ambiente. Devido ao modo de vida bentônico, as arraias de água doce são nadadoras lentas comparadas aos peixes pelágicos. No entanto, com base na morfometria branquial (área de superfície branquial, área branquial massa-específica, barreira de difusão água-sangue, fator de difusão anatômico e abertura relativa do espiráculo), subtipos de estilos de vida podem ser observados: ativas, intermediárias e lentas, conforme escala definida por Gray.

Keywords: Foetus, gill morphology, hypoxia tolerance, potamotrygonid, respiratory area.

\section{Introduction}

Freshwater stingrays (Potamotrygonidae Garman, 1877) occur in major South American rivers that drain into the Atlantic Ocean and Caribbean Sea, with the exception of the Sao Francisco drainages in Brazil. Potamotrygonids vary considerably in their geographical distribution, from widely distributed taxa (Paratrygon aiereba (Müller \& Henle, 1841), Potamotrygon motoro (Müller \& Henle, 1841), and Potamotrygon orbignyi (Castelnau, 1855)) to those with narrow ranges (Plesiotrygon iwamae Rosa, Castello \& Thorson, 1987) as well as endemic species [cururu ray Potamotrygon sp., Potamotrygon leopoldi Castex \& Castello, 1970, and Potamotrygon henlei (Castelnau, 1855)]. The distribution of potamotrygonids has been interpreted to be the result of different habitats (including physicochemical composition) that may act as hydrological barriers to the dispersal of potamotrygonid rays (Duncan \& Fernandes, 2010).

\footnotetext{
${ }^{1}$ Departamento de Morfologia, Universidade Federal do Amazonas, Avenida General Rodrigo Octávio Jordão Ramos, 6.200. Coroado I, 69.077-000 Manaus, Amazonas, Brasil. E-mail: wduncan@ufam.edu.br

${ }^{2}$ Instituto de Ciências Biológicas, Universidade Federal do Amazonas, Avenida General Rodrigo Octávio Jordão Ramos, 6.200, 69077-000 Manaus, Amazonas. E-mail: mariaisa21silva@gmail.com

${ }_{3}^{3}$ Departamento de Ciências Fisiológicas, Universidade Federal de São Carlos, Rodovia Washington Luiz, km 235, 13.565-905 São Carlos, São Paulo, Brasil. E-mail: dmnf@ufscar.br
} 
It has been proposed that some innovation in the gill structures may have favoured tolerance of freshwater environments during the evolution and diversification of potamotrygonids throughout the Amazon Basin (Duncan et al., 2010). The gills are a multifunctional organ involved in gas exchange, acid-base, and ion regulation. The structure and dimensions of the potamotrygonid gills are important parameters with which to assess their function (Duncan et al., 2011). Gill measurements, including the length and abundance of gill filaments, the number of respiratory lamellae on the filaments, lamellar bilateral surface area, total gill surface area, mass-specific gill area, and the water-blood diffusion barrier, are species-specific (Hughes et al., 1986). In addition, some respiratory factors, such as the anatomical diffusion factor and diffusing coefficient, are obtained from these measurements and may reflect the gills' performance under specific environmental conditions (Perry, 1990).

Several studies based on interspecific comparisons have suggested that a large gill respiratory surface in fishes may be a common morphological and physiological response to a hypoxic environment (Crampton et al., 2008). Variation in hypoxia tolerance among potamotrygonid species may contribute to niche-partitioning and the coexistence of closely related taxa in a widely heterogeneous environment. As potamotrygonid rays are found in a wide variety of habitats, including main river channels, floodplain lakes, flooded forest, and both lentic and lotic environments (Rosa et al., 2010), and also considering that several aquatic species may experience profound changes in oxygen availability in the Amazon Basin (Almeida-Val et al., 1999), it is probable that some hypoxia-tolerant potamotrygonids have substantially larger gills than other less tolerant species. The gill dimensions can also be influenced by the level of an animal's activity. Both teleosts and elasmobranchs with high metabolic requirements have gill specialisations facilitating gas transfer (Hughes, 1970; De Jager \& Dekkers, 1975; Wegner et al., 2010). Like teleosts, active pelagic elasmobranchs have a large gill area, densely packed lamellae, and a low water-blood barrier (Hughes \& Wright, 1970). By contrast, sluggish animals have a low metabolic rate and usually possess reduced gill dimensions (Hughes \& Morgan, 1973). Although potamotrygonids can be considered sluggish benthic animals, some species are more active than others. Their activity levels can be deduced from the strategies used to capture prey or from habitat use. Potamotrygonids are carnivorous and prey on a variety of animals (Almeida et al., 2010; Moro et al., 2012; Shibuya et al., 2012). Their hunting tactics include some with high metabolic costs, e.g., undulating their disc margins to disturb the substrate and uncover hidden prey or charging prey concentrated in shallow water (Garrone-Neto \& Sazima, 2009a; Garrone-Neto \& Sazima, 2009b; Garrone-Neto \& Uieda, 2012). Thus, it is possible to summarise the activity patterns of potamotrygonids in accordance with Gray's scale (Gray, 1954), which includes active, intermediate, and sluggish activity levels. The criteria used by Gray's were based on correlation between respiratory area, species activity, and benthic or pelagic life. With this background, it is possible to correlate levels of activity with measurements of potamotrygonid gills.

Another important factor that directly affects gill dimensions is body size. The relationships between gill and body measurements have been investigated for a large number of teleosts, both marine and freshwater species (Karakatsouli et al., 2006; Wegner et al., 2010). To date, such comparisons have only been made for marine elasmobranch species (Emery \& Szczepanski, 1986; Hughes et al., 1986), and few studies have been conducted in freshwater elasmobranchs. In elasmobranchs, warmbodied sharks exhibit larger total gill surface areas than do active, pelagic, ectothermic species (Hughes \& Morgan, 1973). Such large gill areas are necessary to maintain the high oxygen uptake required given their high metabolic rate. However, there are no existing studies on stenohaline freshwater stingrays, especially focusing on variation in gill size among potamotrygonid embryos at birth and the relationship between gill size and habitat characteristics such as oxygen availability. The gill morphology was until now studied only in the adult forms (Duncan et al., 2010, 2011). In this context, the aim of this study was to fully characterise the gill morphometry of near-term foetuses of different potamotrygonid species, thereby contributing to a better understanding of the lifestyle and ecological role of potamotrygonids during the neonatal period.

\section{Material and methods}

Animals. The specimens were collected with the permission of the Chico Mendes Institute for Biodiversity Conservation (ICMBio, the Brazilian federal agency in charge of biodiversity conservation and protected areas/ SISBIO \#22055/2012), and all protocols were conducted in accordance with institutional guidelines for the protection of animal welfare (Ethical Committee of Animal Experimentation, CEUA-UFAM protocol №. 070/2012). The embryos were the result of spontaneous abortions of pregnant females captured using beach seines, gillnets, and bottom longlines by local fisherman during the night in different river systems of the Amazon basin.

Eight pregnant females (mean body mass, $\mathrm{M}_{\mathrm{B}}=0.4 \pm$ $0.01 \mathrm{~kg}$; mean disk width, $\mathrm{D}_{\mathrm{w}}=20.3 \pm 1.4 \mathrm{~cm}$ ) of cururu ray Potamotrygon sp. (an undescribed species) carrying a total of 24 embryos and one pregnant (with four embryos) ocellate river stingray Potamotrygon motoro $\left(\mathrm{M}_{\mathrm{B}}=12 \mathrm{~kg} ; \mathrm{D}_{\mathrm{W}}=62\right.$ $\mathrm{cm}$ ) female were caught in the Negro River (blackwater river, $\mathrm{pH} 4.5 \pm 1.5$, conductivity $12.5 \pm 1.4 \mu \mathrm{S} \mathrm{cm}^{-1}$, total dissolved solids $7.8 \pm 1.1 \mathrm{mg} \mathrm{l}^{-1}$, dissolved oxygen $3.4 \pm 0.7 \mathrm{mg} \mathrm{l}^{-1}$, and temperature $29.8 \pm 1.0^{\circ} \mathrm{C}$ ) near the Barcelos municipality $\left(00^{\circ} 56^{\prime} \mathrm{S} ; 62^{\circ} 55^{\prime} \mathrm{W}\right)$. In the Solimões River (whitewater river, $\mathrm{pH} 7.2 \pm 1.2$, conductivity $103.7 \pm 4.5 \mu \mathrm{S} \mathrm{cm} \mathrm{cm}^{-1}$, total dissolved solids $55.8 \pm 4.1 \mathrm{mg} \mathrm{l}^{-1}$, dissolved oxygen $6.56 \pm 2.8$ 


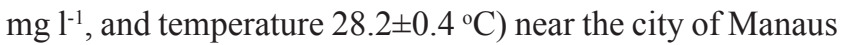
$\left(03^{\circ} 11^{\prime} \mathrm{S} ; 59^{\circ} 33^{\prime} \mathrm{W}\right)$, one pregnant female (with 10 embryos) of Potamotrygon motoro $\left(\mathrm{M}_{\mathrm{B}}=15 \mathrm{~kg} ; \mathrm{D}_{\mathrm{W}}=68 \mathrm{~cm}\right)$ and one of antenna stingray Plesiotrygon iwamae $\left(\mathrm{M}_{\mathrm{B}}=9.5 \mathrm{~kg}\right.$; $\mathrm{D}_{\mathrm{w}}$ $=64 \mathrm{~cm}$ ) carrying four embryos were collected. A female of smoothback river stingray Potamotrygon orbignyi $\left(\mathrm{M}_{B}\right.$ $\left.=4.5 \mathrm{~kg} ; \mathrm{D}_{\mathrm{w}}=41 \mathrm{~cm}\right)$ pregnant with two embryos and a female of manzana ray Paratrygon aiereba $\left(\mathrm{M}_{\mathrm{B}}=20 \mathrm{~kg}\right.$; $\mathrm{D}_{\mathrm{w}}$ $=84 \mathrm{~cm}$ ) with four embryos were caught in the Jutaí River (blackwater river, $\mathrm{pH} 6.7 \pm 2.1$, conductivity $32.8 \pm 2.7 \mu \mathrm{S}$ $\mathrm{cm}^{-1}$, total dissolved solids $17.5 \pm 1.1 \mathrm{mg} \mathrm{l}^{-1}$, dissolved oxygen $4.6 \pm 3.4 \mathrm{mg} \mathrm{l}^{-1}$, and temperature $\left.32.1 \pm 1.0^{\circ} \mathrm{C}\right)$ at the village of Copatana in the Jutai municipality $\left(02^{\circ} 55^{\prime} \mathrm{S} ; 66^{\circ} 57^{\prime} \mathrm{W}\right)$. The adults and embryos were euthanised with neutralised MS222 (Sigma Chemical Co.) $0.5 \mathrm{~g} \mathrm{l}^{-1}$ ). All stingray specimens were identified according to Rosa (1985). One embryo of each potamotrygonid species was included as a voucher specimen in the fish collection at the Federal University of Amazonas. The embryos were at an advanced stage of development, characterised by a well-defined lateral line, reduced external yolk sac, and body coloration as well as developed dentition and fully developed internal organs (Fig. 1). Body mass and linear measurements were recorded for all embryos (Table 1). The length and width of the spiracle were measured using a calliper, and the body surface areas of the embryos (ventral plus dorsal side) were estimated using Image J 1.45s computer software (Wayne Rasband, National Institute of Health, USA) by drawing around the pectoral fins. The caudal and pelvic fins were omitted.

Gill morphometry. The gills were immediately removed and fixed by immersion in $2.5 \%$ phosphate-buffered glutaraldehyde solution with a $\mathrm{pH}$ of 7.4 and an osmolality of approximately $300 \mathrm{mOsmol}$. The shrinkage caused by glutaraldehyde is about 6\% (Hopwood, 1967). However, maintaining osmolality of the fixative tend to minimize shrinkage. Gill area and related dimensions were determined in forty-eight well-developed potamotrygonid embryos. Fixed gill arches from right side of the animal were separated and analysed under a stereoscopic microscope. The gill surface area of an individual arch was estimated using the method established by Hughes (1984) and calculated by the equation $S_{\text {gill }}$ LTF . F lam $_{\text {lam }} . S_{\text {lam }}$, where $S_{\text {gill }}$ is the total surface area, LTF is the total length of the gill filaments, $F_{\text {lam }}$ is lamellar frequency (for both sides of each filament), and $S_{\text {lam }}$ is the mean bilateral surface area of the average secondary lamella. For each potamotrygonid species, all the filaments on the five gill arches of each hemibranch were counted. The length of every $10^{\text {th }}$ filament was estimated, including the first and last one. Total filament length was calculated as the product of the mean filament length and total number of counted filaments, multiplied by two to account for both sides of the animal.

Fixed gill arches from left side of the animal were separated and analysed under a light microscope. The medial filaments of each hemibranch of each gill arch were removed to estimate lamellar frequency. Five gill filaments were divided into tip, middle, and base regions (from medial side), dehydrated through a graded ethanol series and embedded in methacrylate (Historesin, Leica, Heidelberg, Germany). This procedure was used due to the negligible shrinkage of sections and the fish tissue (Cruz et al., 2009). The tissue was sectioned at $3 \mu \mathrm{m}$ sagittally with respect to the filamentary axis and stained with toluidine blue. These sections were used for measurements of lamellar frequency and the water-blood barrier. All observations were made with a light microscope (DM 500, Leica), and digital images were acquired with a digital video camera (Axiocam ERc5s, Carl Zeiss). The lamellar frequency and water-blood diffusion distance were estimated. The thickness of the water-blood barrier was estimated using a test line of a semi-circular grid (Merz's grid) as described by Hughes et al. (1986) and analysed using ImageJ $1.45 \mathrm{~s}$ software. The water-blood barrier was measured at the point of intersection, and a new angle was randomly selected for each histological section analysed. For each animal, the barrier thickness was calculated as $2 / 3$ of the harmonic mean length. The harmonic mean is a better measure of the water-blood distance than the arithmetic mean, because calculation give special weight to the shorter distance (minimum thickness). The anatomical diffusion factor of the water-blood barrier was estimated as the quotient of the mass-specific respiratory surface area $\left(S_{\text {gill }} / \mathrm{M}_{b}\right)$ and 2/3 of the harmonic mean of diffusion barrier thickness (Costa et al., 2007).

Gill samples were processed for scanning electron microscopy procedures. Briefly, the medial filament of the $2^{\text {nd }}$ gill arch was dehydrated through a graded ethanol series and 1,1,1,3,3,3- examethyl-disilazane (Sigma Co., Steinheim, Germany) and air-dried. Dried specimens were mounted on nickel stubs and coated with gold in a vacuum sputter. Twenty intact secondary lamellae from each sampling point (tip, middle, and base) of each hemibranch for each animal were examined under a FEI Quanta 250 scanning electron microscope at $25 \mathrm{kV}$. The digital images acquired of the lamellae were analysed to estimate the lamellar area by tracing the outer edges in a calibrated image using the ImageJ $1.45 \mathrm{~s}$ software program (and multiplying by two).

Statistical analysis. The values of gill morphometry are expressed as the means \pm standard errors. All data were logtransformed prior to statistical analysis. The uniformity of the data was tested using the Kolmogorov-Smirnov test. Comparisons between potamotrygonid species (except in Potamotrygon orbignyi due the small sample size) were made only with the data on lamellar frequency, bilateral lamellae area, water-blood barrier thickness, anatomical diffusion factor, and mass-specific gill surface area. Significant differences between species were tested by a non-parametric ANOVA followed by the Kruskal-Wallis multiple comparison test. Comparisons between the mass-specific gill surface areas of the anterior and posterior hemibranchs (except in the $1^{\text {st }}$ gill arch) were made using a paired Student's t-test. 


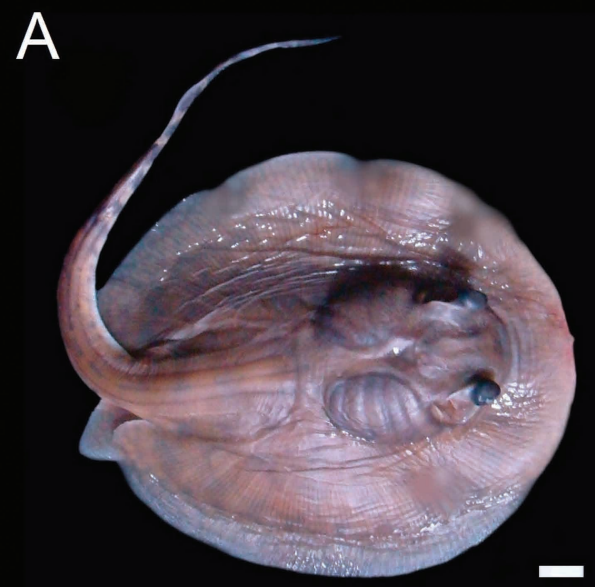

B

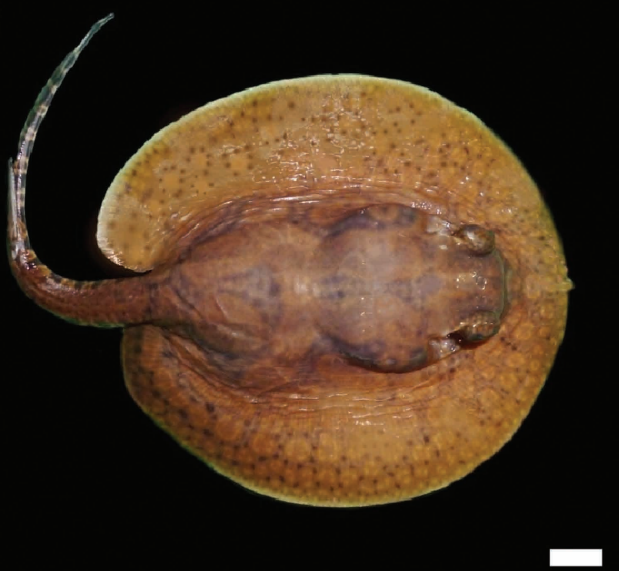

C

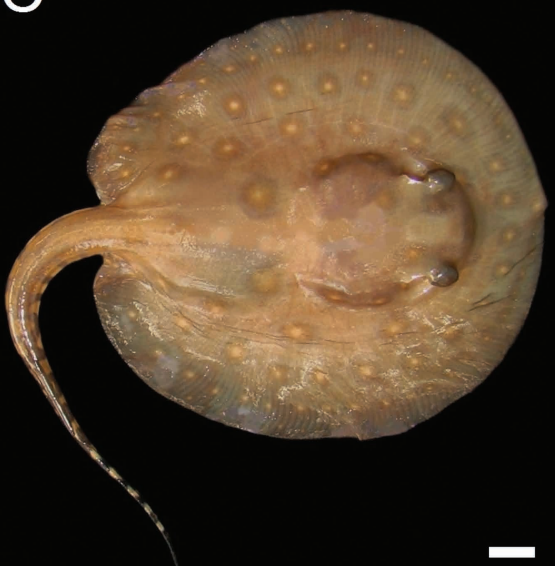

D

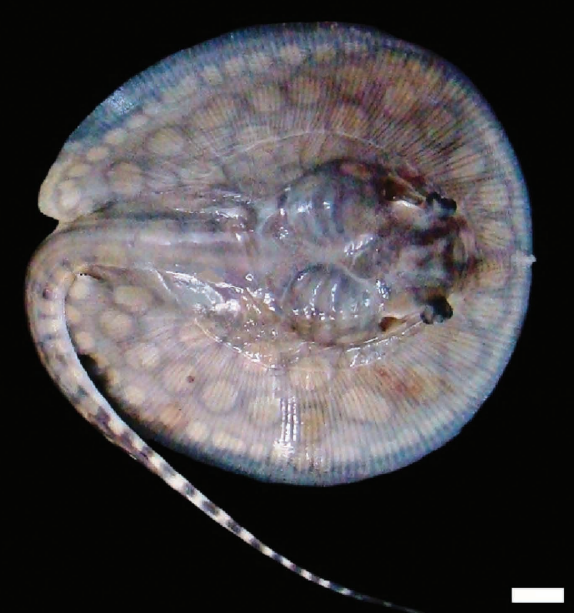

E

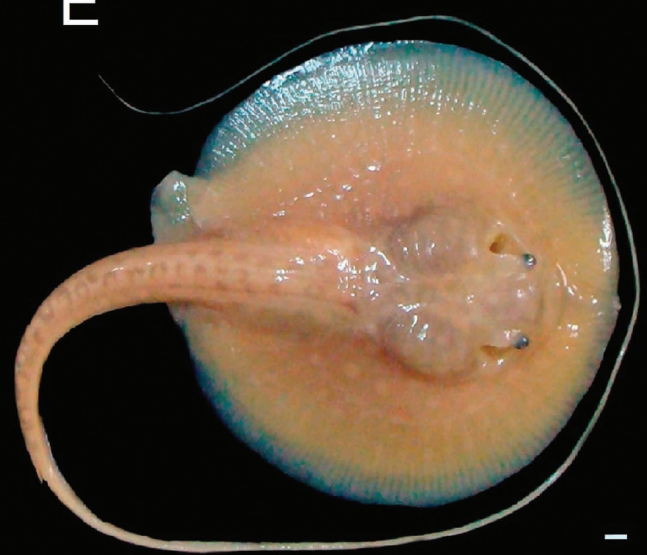

F

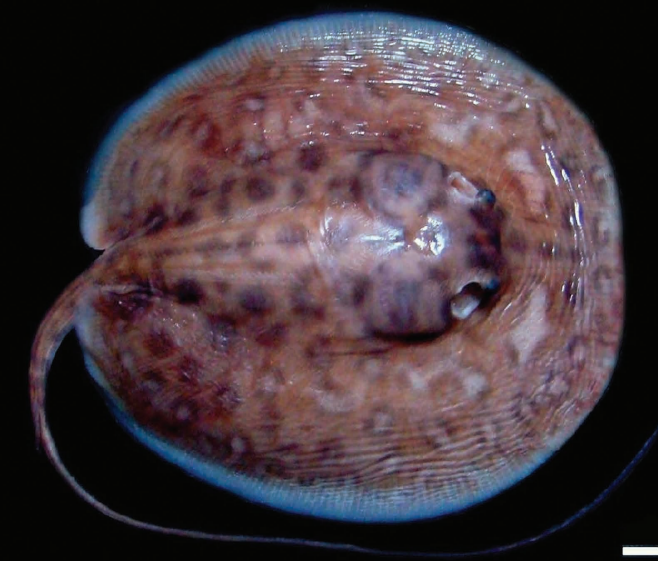

Fig. 1. The potamotrygonid embryos: (A) Potamotrygon orbignyi; (B) cururu ray Potamotrygon sp.; (C) Potamotrygon motoro (from Negro River); (D) Potamotrygon motoro (from Solimões River); (E) Plesiotrygon iwamae; (F) Paratrygon aiereba. Scale bars $=1 \mathrm{~cm}$. 
Principal component analysis (PCA) was applied to the correlation matrix (Pearson) formed by the $\log (x+1)-$ transformed data on the number of total filaments, total gill surface area, mass-specific gill area, anatomical diffusion factor, body mass, superficial body area, and relative opening of the spiracle. The principal component axes retained for interpretation were those with eigenvalues larger than 1.0. Linear regression was used to verify the relationship between mass-specific gill area and body area and that between total gill area and the relative opening of the spiracle. In all tests, a difference of $p<0.05$ was regarded as statistically significant.

\section{Results}

The biometry of the sampled embryos is summarised in Table 1. As expected, the embryos of Paratrygon aiereba were heavier than those of other ray species, and approximately 8 times heavier than the embryos of Potamotrygon sp. Moreover, the body surface area of Paratrygon aiereba was 3.5 times larger than that of Potamotrygon sp. The other species had similar body dimensions to one another, with sizes intermediate between Paratrygon aiereba and Potamotrygon sp.

In relation to the interspecific variation in gill dimensions, the total length of filaments (LTF) of Paratrygon aiereba was higher $(9-39 \%)$ than of the other potamotrygonid embryos (Table 2). This difference was due to the numerous (Table 3) and long gill filaments (Table 4) in these species. Plesiotrygon has a filament length equivalent to those found for other species such as $P$. motoro and P. orbignyi but at a lower density, which reduces the LTF. Potamotrygon sp. has a total number of filaments (TNF) similar to that found in $P$. motoro and P. orbignyi, but they are shorter in Potamotrygon sp. than in the latter species. Thus, as in Plesiotrygon, this reduces the overall length of gill filaments. Although Plesiotrygon and Potamotrygon sp. exhibit similar values for LTF, Plesiotrygon has approximately 2 times more mass and a higher body surface area than Potamotrygon sp.

In general, with respect to variations among the five gill arches, the TNF usually increases from the $1^{\text {st }}$ to the $3^{\text {rd }}$ gill arch, then decreases from the $3^{\text {rd }}$ to $5^{\text {th }}$ arch. In addition, on the $2^{\text {nd }}$ and $3^{\text {rd }}$ arches, the posterior hemibranchs have more filaments than their anterior counterparts. In contrast, on the $4^{\text {th }}$ and $5^{\text {th }}$ arches, the anterior hemibranchs have more filaments than the posterior ones (Table 2). The filaments on the $1^{\text {st }}$ and $5^{\text {th }}$ arches are shorter than on the other gill arches. Usually, the filaments on the $4^{\text {th }}$ arch are longer than on the other gill arches (Table 3 ). In addition, the posterior hemibranch has markedly fewer and shorter filaments than the anterior one. This feature is more prominent on the posterior hemibranch of the $5^{\text {th }}$ gill arch.

Table 1. General body measurements of the potamotrygonid embryos. Values of the mean \pm standard deviation represent body mass, disk width, total length, relative opening of the spiracle ( $\mathrm{ROSp}=$ spiracle length $\mathrm{x}$ spiracle width), and body area. $\mathrm{N}=$ number of animal sampled.

\begin{tabular}{lcccccc}
\hline Species & $\mathrm{N}$ & Body mass $(\mathrm{g})$ & Disk width $(\mathrm{cm})$ & Total length $(\mathrm{cm})$ & ROSp & Body area $\left(\mathrm{cm}^{2}\right)$ \\
\hline Potamotrygon orbignyi & 2 & $59.0 \pm 2.8$ & $11.0 \pm 0.1$ & $22.5 \pm 0.1$ & $1.1 \pm 0.1$ & $168.4 \pm 4.2$ \\
Potamotrygon sp. & 24 & $19.2 \pm 1.4$ & $6.9 \pm 1.1$ & $13.7 \pm 1.9$ & $0.5 \pm 0.1$ & $89.4 \pm 7.4$ \\
Potamotrygon motoro (from Negro River) & 4 & $75.2 \pm 4.2$ & $11.5 \pm 0.3$ & $23.5 \pm 0.4$ & $0.8 \pm 0.1$ & $234.4 \pm 20.4$ \\
Potamotrygon motoro (from Solimões River) & 10 & $44.1 \pm 1.2$ & $10.2 \pm 0.5$ & $22.1 \pm 0.9$ & $1.3 \pm 0.2$ & $158.2 \pm 5.0$ \\
Plesiotrygon iwamae & 4 & $37.7 \pm 6.5$ & $9.7 \pm 0.8$ & $50.6 \pm 2.9$ & $0.6 \pm 0.1$ & $149.5 \pm 10.2$ \\
Paratrygon aiereba & 4 & $152.5 \pm 6.7$ & $15.9 \pm 0.3$ & $42.3 \pm 1.0$ & $1.1 \pm 0.3$ & $314.8 \pm 25.7$ \\
\hline
\end{tabular}

Table 2. Number of total filaments (mean \pm S.E) on different gill arches among near-term potamotrygonid embryos.

\begin{tabular}{|c|c|c|c|c|c|c|c|}
\hline \multicolumn{2}{|c|}{ Gill arches } & \multirow{2}{*}{$\begin{array}{c}\begin{array}{c}\text { Potamotrygon } \\
\text { orbignyi }\end{array} \\
176.0 \pm 1.2\end{array}$} & \multirow{2}{*}{$\begin{array}{c}\text { Potamotrygon sp. } \\
181.5 \pm 5.2\end{array}$} & \multirow{2}{*}{$\begin{array}{c}\begin{array}{c}\text { Potamotrygon } \\
\text { motoro (N-R) }\end{array} \\
195.5 \pm 1.3\end{array}$} & \multirow{2}{*}{$\begin{array}{c}\begin{array}{c}\text { Potamotrygon } \\
\text { motoro }(\mathrm{S}-\mathrm{R})\end{array} \\
186.3 \pm 3.9\end{array}$} & \multirow{2}{*}{$\begin{array}{c}\begin{array}{c}\text { Plesiotrygon } \\
\text { iwamae }\end{array} \\
123.3 \pm 3.1\end{array}$} & \multirow{2}{*}{$\begin{array}{c}\begin{array}{c}\text { Paratrygon } \\
\text { aiereba }\end{array} \\
212.7 \pm 7.2\end{array}$} \\
\hline I & Posterior & & & & & & \\
\hline II & Anterior & $174.0 \pm 1.2$ & $178.7 \pm 5.0$ & $189.5 \pm 4.3$ & $180.7 \pm 3.3$ & $124.0 \pm 2.6$ & $217.3 \pm 7.6$ \\
\hline \multirow{3}{*}{ III } & Posterior & $183.0 \pm 3.5$ & $188.8 \pm 6.2$ & $198.0 \pm 2.9$ & $194.3 \pm 1.9$ & $132.0 \pm 2.0$ & $230.7 \pm 6.4$ \\
\hline & Anterior & $186.0 \pm 4.2$ & $180.8 \pm 8.6$ & $196.5 \pm 3.6$ & $190.7 \pm 2.5$ & $137.3 \pm 5.1$ & $226.0 \pm 6.2$ \\
\hline & Posterior & $175.0 \pm 2.1$ & $187.0 \pm 6.2$ & $206.5 \pm 1.6$ & $192.0 \pm 2.8$ & $131.3 \pm 3.5$ & $228.7 \pm 6.0$ \\
\hline \multirow[t]{2}{*}{ IV } & Anterior & $185.0 \pm 4.9$ & $180.3 \pm 7.1$ & $206.0 \pm 3.5$ & $191.7 \pm 2.0$ & $138.7 \pm 4.9$ & $221.3 \pm 1.5$ \\
\hline & Posterior & $162.0 \pm 1.4$ & $175.5 \pm 5.1$ & $186.5 \pm 1.3$ & $177.3 \pm 3.2$ & $129.3 \pm 2.5$ & $208.7 \pm 4.9$ \\
\hline \multirow[t]{2}{*}{ V } & Anterior & $169.0 \pm 2.1$ & $161.7 \pm 8.1$ & $185.0 \pm 4.4$ & $172.0 \pm 4.9$ & $132.7 \pm 7.5$ & $211.3 \pm 0.6$ \\
\hline & Posterior & $116.0 \pm 1.4$ & $136.9 \pm 6.5$ & $157.5 \pm 5.2$ & $132.7 \pm 3.9$ & $99.3 \pm 4.0$ & $151.3 \pm 2.1$ \\
\hline
\end{tabular}


Table 3. Mean filament length $(\mathrm{mm})($ mean \pm S.E) on different gill arches among near-term potamotrygonid embryos.

\begin{tabular}{|c|c|c|c|c|c|c|c|}
\hline \multicolumn{2}{|c|}{ Gill arches } & \multirow{2}{*}{$\begin{array}{c}\begin{array}{c}\text { Potamotrygon } \\
\text { orbignyi }\end{array} \\
3.8 \pm 0.2\end{array}$} & \multirow{2}{*}{$\begin{array}{c}\text { Potamotrygon sp. } \\
2.3 \pm 0.3\end{array}$} & \multirow{2}{*}{$\begin{array}{c}\begin{array}{c}\text { Potamotrygon } \\
\text { motoro }(\mathrm{N}-\mathrm{R})\end{array} \\
2.9 \pm 0.2\end{array}$} & \multirow{2}{*}{$\begin{array}{c}\text { Potamotrygon } \\
\text { motoro }(\mathrm{S}-\mathrm{R})\end{array}$} & \multirow{2}{*}{$\begin{array}{c}\begin{array}{c}\text { Plesiotrygon } \\
\text { iwamae }\end{array} \\
2.8 \pm 1.3\end{array}$} & \multirow{2}{*}{$\begin{array}{c}\text { Paratrygon } \\
\text { aiereba }\end{array}$} \\
\hline I & Posterior & & & & & & \\
\hline II & Anterior & $4.1 \pm 0.1$ & $2.3 \pm 0.3$ & $3.3 \pm 0.2$ & $3.3 \pm 1.1$ & $3.1 \pm 1.4$ & $4.8 \pm 0.4$ \\
\hline \multirow{3}{*}{ III } & Posterior & $4.4 \pm 0.2$ & $2.4 \pm 0.4$ & $3.3 \pm 0.2$ & $3.4 \pm 1.1$ & $3.2 \pm 1.4$ & $5.1 \pm 0.4$ \\
\hline & Anterior & $4.4 \pm 0.2$ & $2.5 \pm 0.4$ & $3.9 \pm 0.1$ & $3.7 \pm 0.8$ & $3.4 \pm 1.4$ & $5.1 \pm 0.4$ \\
\hline & Posterior & $4.3 \pm 0.1$ & $2.5 \pm 0.3$ & $3.5 \pm 0.3$ & $3.1 \pm 1.2$ & $3.4 \pm 1.5$ & $5.0 \pm 0.1$ \\
\hline \multirow[t]{2}{*}{ IV } & Anterior & $4.5 \pm 0.1$ & $2.6 \pm 0.4$ & $3.7 \pm 0.3$ & $3.4 \pm 1.3$ & $3.6 \pm 1.3$ & $5.1 \pm 0.1$ \\
\hline & Posterior & $4.3 \pm 0.2$ & $2.5 \pm 0.3$ & $3.5 \pm 0.3$ & $3.3 \pm 1.3$ & $3.6 \pm 1.6$ & $5.0 \pm 0.3$ \\
\hline \multirow[t]{2}{*}{$\mathrm{V}$} & Anterior & $4.4 \pm 0.1$ & $2.7 \pm 0.5$ & $3.6 \pm 0.2$ & $3.4 \pm 1.2$ & $3.5 \pm 1.4$ & $4.8 \pm 0.2$ \\
\hline & Posterior & $3.8 \pm 0.1$ & $2.3 \pm 0.3$ & $3.4 \pm 0.8$ & $3.3 \pm 1.0$ & $3.2 \pm 1.4$ & $4.1 \pm 0.2$ \\
\hline
\end{tabular}

Table 4. Total filament lengths $(\mathrm{mm})(\mathrm{mean} \pm$ S.E) of different gill arches among near-term potamotrygonid embryos.

\begin{tabular}{|c|c|c|c|c|c|c|c|}
\hline \multicolumn{2}{|c|}{ Gill arches } & Potamotrygon & Potamotrygon & Potamotrygon & Potamotrygon & Plesiotrygon & Paratrygon \\
\hline I & Posterior & $673.7 \pm 13.5$ & $388.3 \pm 33.8$ & $578.2 \pm 24.7$ & $558.8 \pm 39.2$ & $344.6 \pm 24.9$ & $963.7 \pm 22.6$ \\
\hline \multirow[t]{2}{*}{ II } & Anterior & $712.9 \pm 4.7$ & $414.3 \pm 35.1$ & $618.7 \pm 30.5$ & $641.9 \pm 28.1$ & $387.0 \pm 18.5$ & $1033.8 \pm 22.9$ \\
\hline & Posterior & $801.1 \pm 28.6$ & $445.3 \pm 43.2$ & $661.0 \pm 30.6$ & $689.0 \pm 19.9$ & $418.9 \pm 20.6$ & $1169.5 \pm 53.3$ \\
\hline \multirow[t]{2}{*}{ III } & Anterior & $813.8 \pm 3.9$ & $455.2 \pm 45.3$ & $778.0 \pm 33.3$ & $743.4 \pm 28.0$ & $466.1 \pm 39.6$ & $1148.3 \pm 44.5$ \\
\hline & Posterior & $745.6 \pm 1.1$ & $469.6 \pm 41.4$ & $720.4 \pm 26.6$ & $668.3 \pm 36.6$ & $444.2 \pm 33.6$ & $1138.8 \pm 24.3$ \\
\hline \multirow[t]{2}{*}{ IV } & Anterior & $828.2 \pm 22.5$ & $465.2 \pm 42.2$ & $784.1 \pm 45.4$ & $714.7 \pm 28.6$ & $500.2 \pm 38.4$ & $1133.6 \pm 11.5$ \\
\hline & Posterior & $695.0 \pm 23.8$ & $440.0 \pm 34.9$ & $652.2 \pm 33.5$ & $631.8 \pm 26.6$ & $462.0 \pm 23.7$ & $1035.8 \pm 52.2$ \\
\hline \multirow[t]{2}{*}{ V } & Anterior & $736.2 \pm 3.3$ & $429.9 \pm 38.1$ & $659.1 \pm 43.8$ & $638.8 \pm 27.4$ & $459.3 \pm 28.4$ & $1007.0 \pm 22.0$ \\
\hline & Posterior & $435.4 \pm 9.9 .6$ & $316.0 \pm 28.2$ & $549.3 \pm 19.8$ & $461.9 \pm 20.7$ & $315.3 \pm 15.9$ & $614.3 \pm 8.7$ \\
\hline
\end{tabular}

Likewise, the variation in the total superficial gill area of each hemibranch and gill arch was similar to that found for the gill metrics. Among the gill arches, the total gill area increases from the $1^{\text {st }}$ to $4^{\text {th }}$ arch (Figs. 2a, b, c, $\mathrm{d}, \mathrm{e})$. In contrast, in Paratrygon, the surface area tends to decrease from the $2^{\text {nd }}$ to $5^{\text {th }}$ gill arch (Fig. 2f). The posterior hemibranch of the $5^{\text {th }}$ gill arch shows a reduced gill area compared all other hemibranchs. Among potamotrygonid embryos, Potamotrygon sp. and Plesiotrygon iwamae (Figs. 2b, e) have a lower gill surface area for all gill arches compared to their counterparts. However, when taking body mass into account, the surface area among gill arches of Potamotrygon sp. (Fig. 3b) is similar to the values found for P. orbignyi (Fig. 3a) and P. motoro (Figs. 3c, d). Due to their larger body size, the gill arches of Plesiotrygon (Fig. 3e) and Paratrygon (Fig. 3f) have a low mass-specific gill area compared to other potamotrygonid embryos. This feature can also be noted in Fig. 4.

Obvious differences among potamotrygonid embryos were also observed in lamellar frequency, bilateral lamellae area, water-blood diffusion barrier thickness, the anatomical diffusion factor, and total gill area (Table 5). Paratrygon aiereba and Plesiotrygon iwamae exhibited a low frequency of lamellae relative to the other species. Unlike Plesiotrygon iwamae, the surface area of individual lamellae of Paratrygon aiereba was similar to that of the others rays. As commented above, Paratrygon possesses numerous and larger filaments, and this significantly increases its total gill area to $>120 \mathrm{~cm}^{2}$. However, P. orbignyi and P. motoro (from the Solimões River) also exhibited comparable gill areas to those reported for Paratrygon embryos. Despite having a larger gill area, the water-blood diffusion barrier was thicker in Paratrygon aiereba $(2 / 3$ harmonic mean $=2.63 \pm 0.37 \mu \mathrm{m})$ than in those other potamotrygonid embryos. P. orbignyi and P. motoro (from Solimões River) were found to have significantly thinner water-blood distances $(1.17 \pm 0.18$ and $1.48 \pm 0.12$ $\mu \mathrm{m}$, respectively). Because of this, the anatomic diffusion factor (ADF) in those species is relatively higher $\left(\sim 1.7 \mathrm{~cm}^{2}\right.$ $\left.\mathrm{g}^{-1} \mu \mathrm{m}^{-1}\right)$ than that observed for Paratrygon and Plesiotrygon (0.2 and $0.3 \mathrm{~cm}^{2} \mathrm{~g}^{-1} \mu \mathrm{m}^{-1}$, respectively). Looking at a triplot of ADF, water-blood barrier thickness, and mass-specific gill area (Fig. 5), the embryos of P. orbignyi and P. motoro have a higher ADF with a larger mass-specific gill area and a thin water-blood diffusion barrier, whereas Paratrygon aiereba and Plesiotrygon iwamae exhibited low ADF, a smaller mass-specific gill area, and thick water-blood barriers. Despite of Potamotrygon sp. embryo having a high $\mathrm{ADF}$ and mass-specific gill area, the water-blood barrier thickness was intermediate between the values observed for other potamotrygonids. 


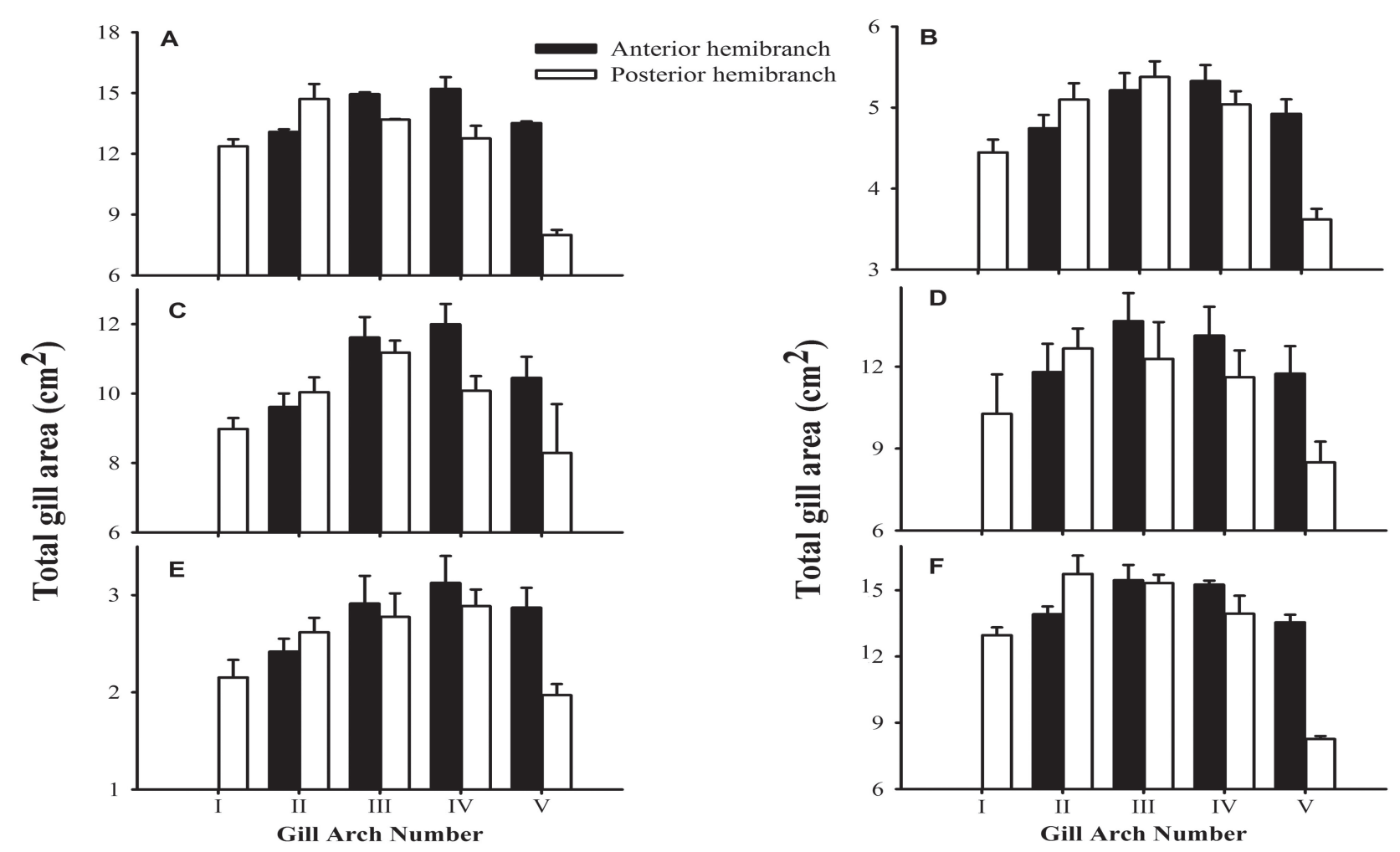

Fig. 2. Total superficial gill area of the anterior and posterior hemibranchs of the gill arches in different potamotrygonid embryos: (A) Potamotrygon orbignyi; (B) Potamotrygon sp.; (C) Potamotrygon motoro (from Negro River); (D) Potamotrygon motoro (from Solimões River); (E) Plesiotrygon iwamae; (F) Paratrygon aiereba.
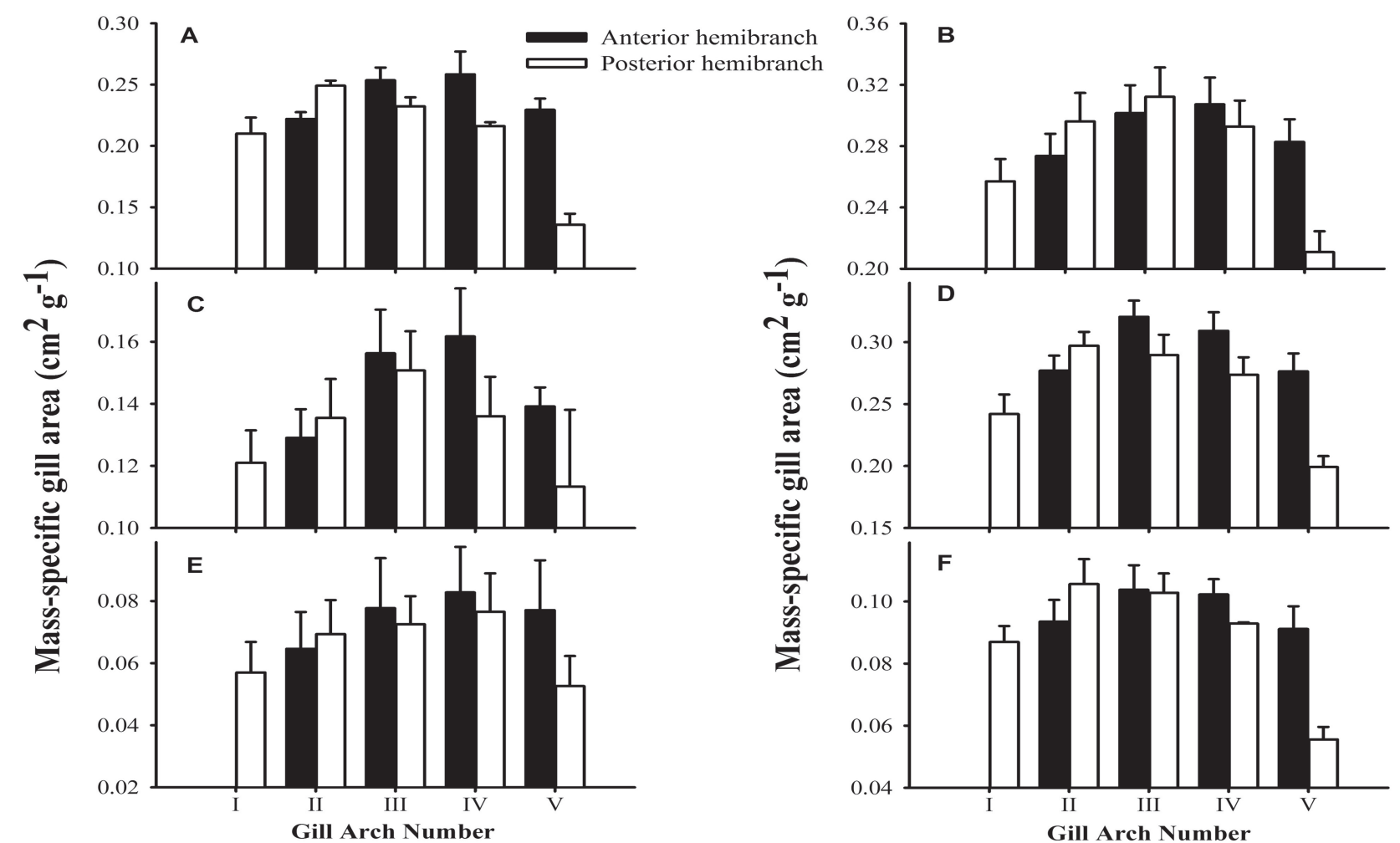

Fig. 3. Mass-specific gill area of the anterior and posterior hemibranchs of the gill arches in different potamotrygonid embryos: (A) Potamotrygon orbignyi; (B) Potamotrygon sp.; (C) Potamotrygon motoro (from Negro River); (D) Potamotrygon motoro (from Solimões River); (E) Plesiotrygon iwamae; (F) Paratrygon aiereba. 


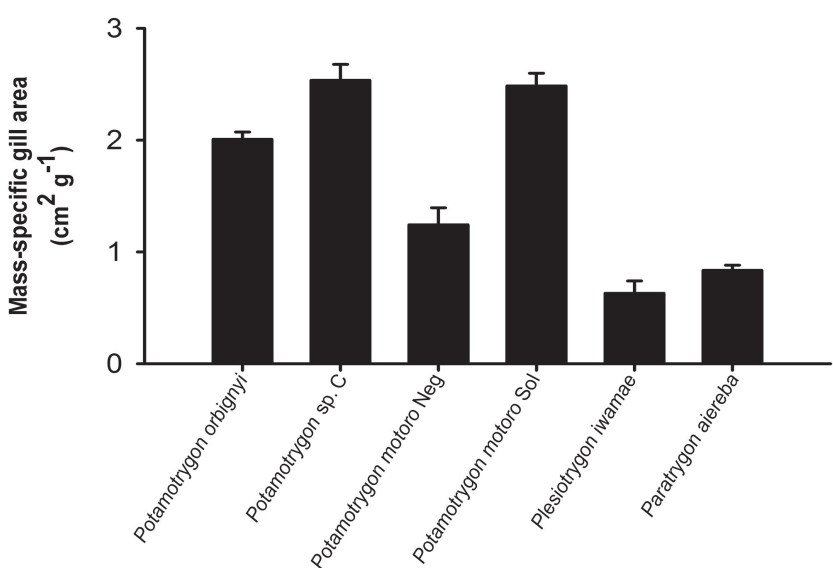

Fig. 4. Mass-specific surface area of the gills of different potamotrygonid embryos.

Two principal component axes (axis 1 - component 1 and axis 2 - component 2) presented eigenvalues greater than 1.0 and were retained for interpretation. These two axes together explained $86.7 \%$ of the variability in gill morphometry (component 1, 56.6\% and component 2, 30.1\%). The relative opening of the spiracle, total gill surface area, and body surface area were positively correlated with component 1
(Table 6). Component 2 was associated positively with the total number of filaments and mass-specific gill surface area and negatively with body surface area. Based on the scatter plot of the gill measurements projected onto the first two axes of the PCA (Fig. 6), a linear regression analysis revealed that mass-specific gill area is inversely related to surface body area (mass-specific gill area $=3.36-(0.67$ $\mathrm{x}$ surface body area), $\mathrm{r}=0.68 ; \mathrm{p}=0.001$ ), whereas total gill area is positively related to the relative opening of the spiracle (total gill area $=1.97+(0.96 \mathrm{x}$ relative opening of the spiracle), $r=0.83 ; p=0.001$ ) (Fig. 7).

Fifty-four characters obtained from the log-transformed morphometric data (including all hemibranchs of the five gill arches) were used to perform the cluster analysis. A dendrogram based on Euclidean distances (single linkage) between the embryos of the five potamotrygonid species, including P. motoro specimens from the Negro and Solimões rivers is shown in Fig. 8. The ray embryos were clustered (Euclidean distance 0.6) into four groups. P. motoro (both populations) and $P$. orbignyi are closest in proximity. Paratrygon embryos were found to be more closely related to $P$. motoro and P. orbignyi than Potamotrygon sp., whereas Plesiotrygon iwamae and Potamotrygon sp. are far apart and distant from the other embryo species.

Table 5. General gill dimensions (mean \pm S.E) in potamotrygonid embryos. ${ }^{\dagger}$ Both sides of the animal. Different letters indicate a significant difference $(\mathrm{p}<0.05)$ between potamotrygonid species.

\begin{tabular}{|c|c|c|c|c|c|}
\hline Species & $\begin{array}{c}\text { Lamellae } \\
\text { frequency } \\
\left(\text { number } \mathrm{mm}^{-1}\right)\end{array}$ & $\begin{array}{l}\text { Bilateral lamellae } \\
\text { area }\left(\times 10^{-3} \mathrm{~mm}^{2}\right)\end{array}$ & $\begin{array}{l}\text { Water-blood barrier } \\
\text { thickness } 2 / 3 \text { harmonic } \\
\text { mean }(\mu \mathrm{m})\end{array}$ & $\begin{array}{c}\text { Anatomic } \\
\text { diffusion factor } \\
\left(\mathrm{cm}^{2} \mathrm{~g}^{-1} \mu \mathrm{m}^{-1}\right)\end{array}$ & $\begin{array}{l}\text { Total gill } \\
\text { area }^{\dagger} \\
\left(\mathrm{cm}^{2}\right)\end{array}$ \\
\hline Potamotrygon orbignyi & $35.8 \pm 1.6^{\mathrm{a}}$ & $54.1 \pm 4.4^{\mathrm{a}}$ & $1.2 \pm 0.2^{\mathrm{a}}$ & $1.72 \pm 0.06^{\mathrm{a}}$ & $118.3 \pm 0.1^{\mathrm{a}}$ \\
\hline Potamotrygon sp. & $40.2 \pm 2.4^{b}$ & $28.3 \pm 1.5^{\mathrm{b}}$ & $2.2 \pm 0.2^{\mathrm{b}}$ & $1.13 \pm 0.06^{\mathrm{b}}$ & $49.8 \pm 1.5^{\mathrm{b}}$ \\
\hline Potamotrygon motoro (from Negro River) & $43.2 \pm 2.5^{\mathrm{b}}$ & $36.5 \pm 1.4^{\mathrm{c}}$ & $2.1 \pm 0.1^{\mathrm{b}}$ & $0.61 \pm 0.05^{\mathrm{c}}$ & $92.8 \pm 3.5^{\mathrm{c}}$ \\
\hline Potamotrygon motoro (from Solimões River) & $42.2 \pm 3.3^{\mathrm{b}}$ & $41.2 \pm 1.6^{\mathrm{d}}$ & $1.5 \pm 0.1^{\mathrm{a}}$ & $1.68 \pm 0.08^{\mathrm{a}}$ & $105.7 \pm 2.6^{\mathrm{d}}$ \\
\hline Plesiotrygon iwamae & $28.4 \pm 2.3^{c}$ & $22.7 \pm 3.4^{\mathrm{b}}$ & $2.9 \pm 0.2^{\mathrm{d}}$ & $0.21 \pm 0.04^{\mathrm{d}}$ & $23.7 \pm 1.7^{\mathrm{e}}$ \\
\hline Paratrygon aiereba & $30.6 \pm 2.1^{\mathrm{ac}}$ & $44.3 \pm 1.4^{\mathrm{d}}$ & $2.6 \pm 0.4^{\mathrm{bd}}$ & $0.32 \pm 0.02^{\mathrm{d}}$ & $124.4 \pm 1.4^{\mathrm{f}}$ \\
\hline
\end{tabular}

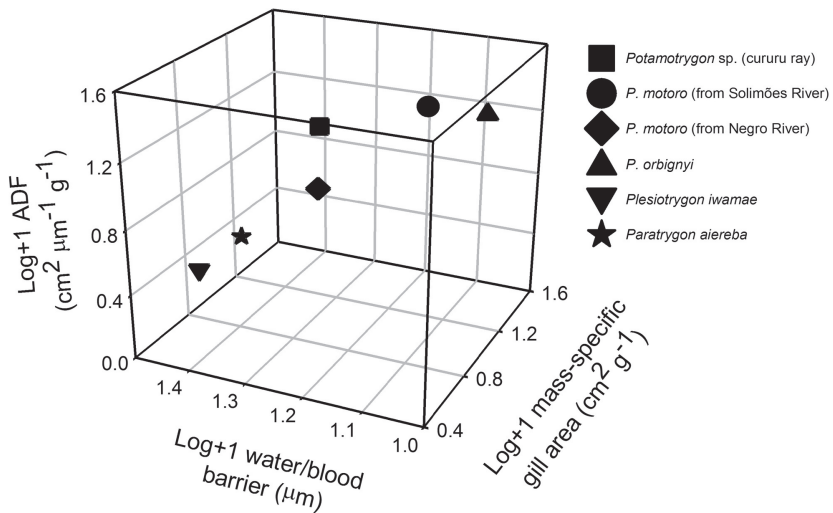

Fig. 5. Triplot of log (Anatomic Diffusion Factor) versus $\log$ (water/blood barrier thickness) versus $\log$ (mass-specific gill area) of the potamotrygonid embryos.
Table 6. The two main morphological principal component axes and the loading per morphological character. Highest loadings are highlighted in asterisk. The eigenvalues and percentages of explainable variance on the first two PCA axes are listed below.

\begin{tabular}{lcc}
\hline & Component 1 & Component 2 \\
\hline Number of filaments & 0.33 & $0.53^{*}$ \\
Mass-specific gill area & -0.19 & $0.73^{*}$ \\
Total gill area & $0.55^{*}$ & 0.26 \\
Opening of spiracle & $0.52^{*}$ & 0.01 \\
Body area & $0.52^{*}$ & -0.35 \\
Eigenvalue & 2.83 & 1.50 \\
Variance $(\%)$ & 56.6 & 30.1 \\
\hline
\end{tabular}




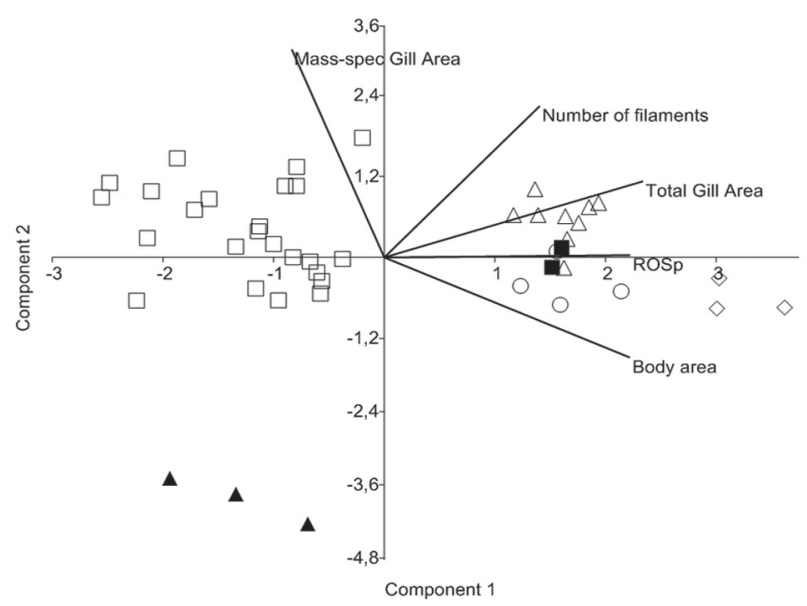

Fig. 6. The two main axes of a principal component analysis based on total gill area, mass-specific gill area, body mass, total length, Anatomical Diffusion Factor and Relative Opening of Spiracule (ROSp) in the different potamotrygonid embryos: black triangle - Plesiotrygon iwamae; open diamond - Paratrygon aiereba; circle Potamotrygon motoro (from Negro River); open triangle Potamotrygon motoro (from Solimões River); black square - Potamotrygon orbignyi; open square - Potamotrygon sp. (cururu ray).
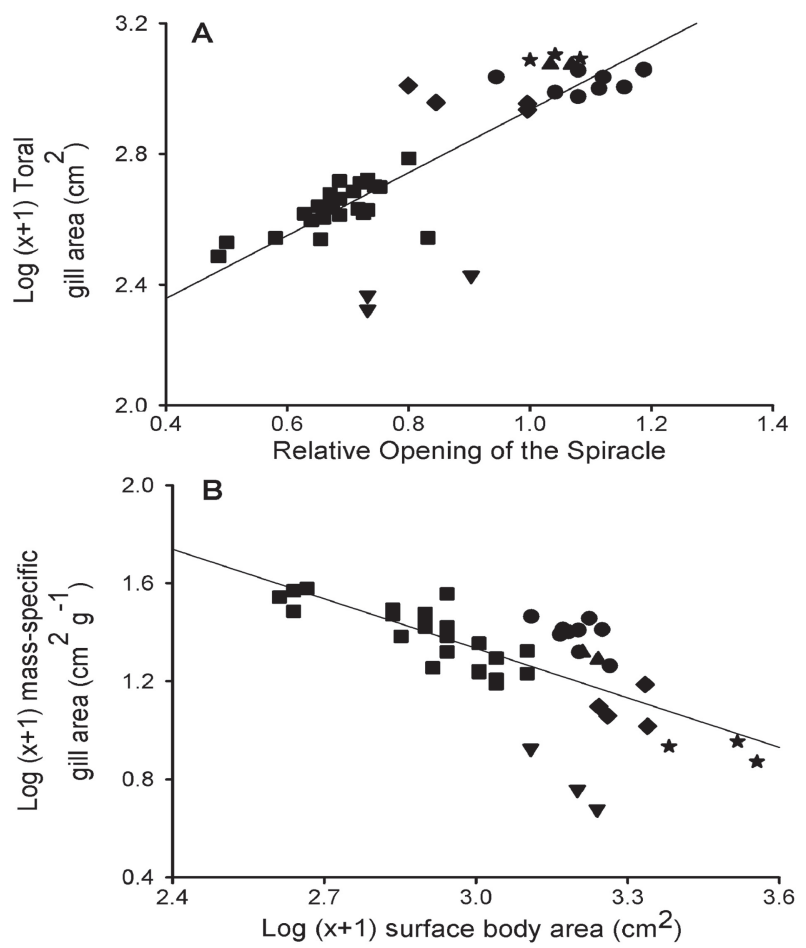

Fig. 7. (A) The relationship between total gill area $\left(\mathrm{cm}^{2}\right)$ and Relative Opening of the spiracle. (B) Linear regression of the mass-specific gill area $\left(\mathrm{cm}^{2} \mathrm{~g}^{-1}\right)$ and body surface area $\left(\mathrm{cm}^{2}\right)$ of different potamotrygonid embryos: upsidedown triangle - Plesiotrygon iwamae; star - Paratrygon aiereba; diamond - Potamotrygon motoro (from Negro River); dot - Potamotrygon motoro (from Solimões River); triangle Potamotrygon orbignyi; square - cururu ray Potamotrygon sp.

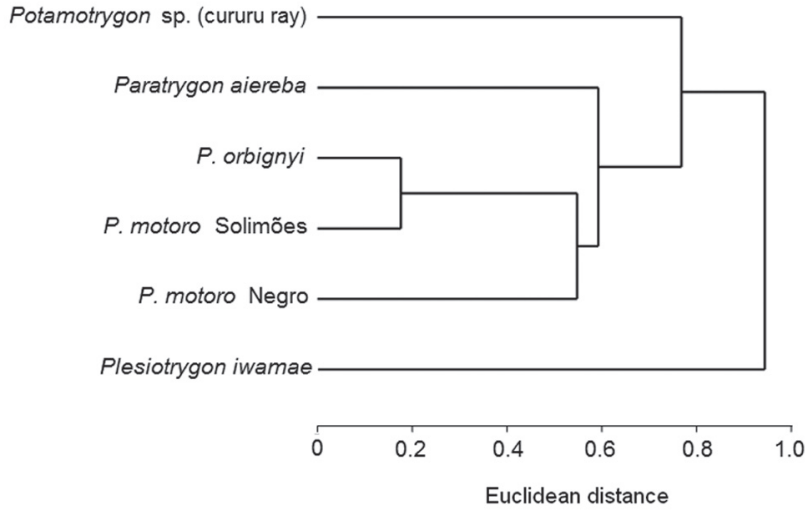

Fig. 8. Dendrogram showing the association of freshwater stingrays based on the gill morphometry of the embryos.

\section{Discussion}

Morphometric variations among gill arches. In a previous study, it was reported that the gill arches of potamotrygonids are not identical structural units in the branchial system (Duncan et al., 2011). It was suggested that the $4^{\text {th }}$ gill arch is more relevant for osmoregulation and ion balance. Comparing the five gill arches, those authors demonstrated that the $4^{\text {th }}$ branchial arch in both Paratrygon aiereba and Potamotrygon sp. possesses a high density of $\mathrm{Na}^{+} / \mathrm{K}^{+}$- ATPase-rich, mitochondrionrich cells and high enzyme activity of $\mathrm{Na}^{+} / \mathrm{K}^{+}$- ATPase. In addition, the $3^{\text {rd }}$ gill arch has a higher surface area than the other arches. As in adults, all potamotrygonid embryos had a $3^{\text {rd }}$ gill arch with a higher surface area. This pattern is similar to that found for the teleost fish Sparus aurata L. 1758 (Karakatsouli et al., 2006). Disregarding the $1^{\text {st }}$ arch, which has only a posterior hemibranch, the $5^{\text {th }}$ arch is characterised by relatively shorter and lower-density filaments, especially on the posterior hemibranch. This dramatically reduces the gill area of this arch. An explanation for this is that water flow is different for each region of the parabranchial cavity, as observed in the hedgehog skate Leucoraja erinacea (Mitchill, 1825), a non-ram-ventilating elasmobranch (Summers \& Ferry-Graham, 2001). It is likely that the geometry and hydrodynamics in the gill chamber of potamotrygonids may explain why, with the exception of the $2^{\text {nd }}$ arch, the anterior hemibranchs have a larger gill area than the posterior hemibranchs. This differs from other data obtained for marine elasmobranchs. In the nursehound (Scyliorhinus stellaris), the filaments of the posterior hemibranchs are longer than those of the anterior hemibranchs except for the $5^{\text {th }}$ arch (Hughes et al., 1986). Longer posterior hemibranchs in the $2^{\text {nd }}$ and $5^{\text {th }}$ arches are at least one common morphological character between potamotrygonids and marine elasmobranchs. However, it is important to emphasise that the nursehound is shark-like, although anatomically it has a slightly flattened head. 
Interspecific variations among potamotrygonid embryos. There are no existing studies of the gill morphometry of ray embryos that can facilitate adequate comparisons. Here, comparisons between the foetuses of different species of potamotrygonids could be made considering only the swimming behaviour of the adult freshwater stingrays in benthic environments. Unfortunately, the criteria for estimating degree of activity are not based on oxygen measurements. Instead, such estimations consider only the swimming behaviour of adult animals. Gill structures vary in relation to the activity and habitat use of freshwater stingrays. The present investigation reveals three distinct groups within potamotrygonid embryos: (i) Active species are characterised by the presence of a large body surface area, large gill area, higher mass-specific gill area, thin waterblood diffusion barrier, high anatomical diffusion factor (ADF), and greater relative opening of the spiracle. In this group are included Potamotrygon motoro and Potamotrygon orbignyi; (ii) Intermediate species have a small body area but a large mass-specific gill area; although the gill area is small, it has a high ADF. Potamotrygon sp. is the only one that fits this pattern; (iii) Sluggish rays are characterised by a very low mass-specific gill area, an extremely low ADF value, a reduced relative opening of the spiracle, and a thick water-blood diffusion barrier. The genera Paratrygon and Plesiotrygon may be included in this group.

Several authors agree that gill area is linked to the activity of the fish (Gray, 1954; Wegner et al., 2010). For example, the gill filament number is higher in the faster swimming Atlantic sharpnose Rhizoprionodonterraenovae (Richardson, 1836) than in more benthic smooth dogfish shark Mustelus canis (Mitchill, 1815) (Schwartz et al., 1993). However, these species belong to different taxonomic groups, and any comparisons need to be cautious. Such large gill areas are undoubtedly necessary to facilitate more oxygen uptake and sustain the high metabolic requirements of active species. Active potamotrygonid swimmers, such as $P$. orbignyi and $P$. motoro possess longer and more numerous filaments, correlated with denser secondary lamellae, which dramatically increases gill surface area than more sluggish rays. Furthermore, this high lamellar frequency is associated with a thin respiratory epithelium. The water-blood diffusion barrier thickness in active potamotrygonid embryos ranges from 1.2 to $1.5 \mu \mathrm{m}$. These values are substantially lower than their marine relatives, but surprisingly near to the range $(0.5-1.2 \mu \mathrm{m})$ reported for scombrid teleosts (Hughes, 1970; Wegner et al., 2010). The water-blood barrier distance in marine rays $(5.5 \mu \mathrm{m})$ is lower than in freeswimming elasmobranchs $(10.2 \mu \mathrm{m})$ (Hughes \& Wright, 1970; Hughes et al., 1986). However, active freshwater stingrays have a mass-specific gill area in the same range $\left(1.2-2.5 \mathrm{~cm}^{2} \mathrm{~g}^{-1}\right)$ as those values $\left(2.6 \mathrm{~cm}^{2} \mathrm{~g}^{-1}\right)$ observed for the marine elasmobranch Scyliorhinus stellaris, weighing approximately $100 \mathrm{~g}$ (Hughes \& Wright, 1970). Therefore, for an animal weighing 1,000 $\mathrm{g}$, mass-specific gill area is reduced to $2 \mathrm{~cm}^{2} \mathrm{~g}^{-1}$. This is consistent with the values found for adult potamotrygonids (cururu ray Potamotrygon sp.) in which the gill area is $<1 \mathrm{~cm}^{2} \mathrm{~g}^{-1}$ (Duncan et al., 2011). Despite this relatively reduced gill area, the thin waterblood barrier is the largest contributor to the increase in the gill anatomical diffusion factor (ADF, $\sim 1.7 \mathrm{~cm}^{2} \mathrm{~g}^{-1} \mu \mathrm{m}^{-1}$ ) for $\mathrm{O}_{2}$ uptake. ADF, a measure of the morphological potential for gas exchange normalised to body mass, falls within the same range as juvenile rainbow trout Oncorhynchus mykiss (Walbaum, 1792). Perry (1990) calculated ADF for a $25 \mathrm{~g}$ rainbow trout to be approximately $1 \mathrm{~cm}^{2} \mathrm{~g}^{-1} \mu \mathrm{m}^{-1}$. However, Wells \& Pinder (1996) has shown that ADF in rainbow trout is high at hatch, approximately $2.6 \mathrm{~cm}^{2} \mathrm{~g}^{-1} \mu \mathrm{m}^{-1}$.

Compared to $P$. motoro and P. orbignyi, Potamotrygon $\mathrm{sp}$. has a thick water-blood barrier but a large massspecific gill area, which directly contributes to increasing the $\operatorname{ADF}\left(1.1 \mathrm{~cm}^{2} \mathrm{~g}^{-1} \mu \mathrm{m}^{-1}\right)$ to a value close to those of the potamotrygonids previously reported. At birth, Potamotrygon sp. has one of the lowest total gill surface areas $\left(<50 \mathrm{~cm}^{2}\right)$ compared to other freshwater stingrays. This is due to the small body mass (only $19 \mathrm{~g}$ ) of this species. However, when the gill area is expressed as a ratio of weight, this value $\left(2.4 \mathrm{~cm}^{2} \mathrm{~g}^{-1}\right)$ is similar to those found for P. motoro and P. orbignyi. According to Gray's scale adapted for potamotrygonids, Potamotrygon sp. is an intermediate species. However, Potamotrygon sp. possesses a high density of mitochondrion rich-cells $\left(\mathrm{Na}^{+} /\right.$ $\mathrm{K}^{+}$-ATPase-rich chloride cells, NKA-MRC) clustered in a follicular arrangement in the interlamellar epithelium and also distributed in single form in the lamellae. The high number of NKA-MRCs in the lamellae may account for improved ion uptake from the ion-poor blackwater of the Negro River and its tributaries (Duncan et al., 2010, 2011). Freshwater stingrays are in a net negative ion balance in ion-poor waters (Wood et al., 2002), and almost certainly, the deficit is normally made up by the electrolytes in their natural diet and high levels of electrogenic ions pumped through the gills (Duncan et al., 2009). Chloride cell proliferation is typical for some fish exposed to diluted water, and it may reduce the efficiency of oxygen uptake by increasing the thickness of the water-blood diffusion barrier (Sakuragui et al., 2003). Thus, a modification that enhances one process may impair another. This trade-off between respiratory gas exchange and ionic regulation has been termed the osmo-respiratory compromise (Fernandes et al., 2007). As has been reported for adult forms (Duncan et al., 2011), embryos of Potamotrygon sp. possess a high mass-specific gill area, which is necessary to facilitate adequate levels of oxygen uptake. This accords with the life habits of this species, which spends much of its time foraging at the bottom of flooded forest (also called as Igapó forest), which is characterised by hypoxic conditions.

In contrast, the gill morphometry of Paratrygon aiereba and Plesiotrygon iwamae most closely resembles that of the gills of sluggish fish. Both species are characterised 
by fairly low mass-specific gill areas $\left(<1 \mathrm{~cm}^{2} \mathrm{~g}^{-1}\right)$ and relatively thick water-blood diffusion barriers (2.6-2.9 $\mu \mathrm{m})$, and consequently, a lower ADF $\left(0.2-0.3 \mathrm{~cm}^{2} \mathrm{~g}^{-1}\right.$ $\left.\mu \mathrm{m}^{-1}\right)$ than in other potamotrygonid species. The estimate of diffusing gas capacity (Dg) for this species of 0.03-0.05 $\mathrm{ml} \mathrm{O}_{2} \mathrm{~min}^{-1} \mathrm{~mm} \mathrm{Hg}^{-1} \mathrm{~g}^{-1}$, which is the theoretical maximum value expected, indicates a low metabolism. This low Dg, when compared to those reported by Hughes (1984), suggests a sluggish mode of life. Plesiotrygon iwamae preferentially inhabits the main stem of the Amazon River and its várzea lakes (floodplain lake), but only those with running water (Duncan et al., 2010). Like Plesiotrygon, Paratrygon aiereba prefer the main river channel and its flooded forests (várzea or igapó). However, Paratrygon is found in multiple different water types (black-, white, and clearwater), whereas Plesiotrygon moves slowly on the river bottom.

Mass-specific gill area varies inversely with body dimensions. Over the past 60 years, much effort has been direct towards establishing the relationship between gill area and body weight for a number of species, including elasmobranchs (Gray, 1954; Hughes \& Wright, 1970; Hughes et al., 1986). Potamotrygonids vary considerably in body mass, from small size (e.g., Potamotrygon sp.) to large size (Paratrygon aiereba). Adults of Potamotrygon sp., a very small species known as a "dwarf freshwater stingray", weigh approximately $0.8 \mathrm{~kg}$ (Charvet-Almeida et al., 2005; Duncan \& Fernandes, 2010), whereas Paratrygon aiereba is the largest freshwater stingray known to date, and adult specimens may weigh over 113 $\mathrm{kg}$ (Barbarino \& Lasso, 2009). The great difference in the body masses of these species also reflects in the size of the foetus and neonate. The embryos of Paratrygon at birth are 8 times greater in mass than those of Potamotrygon sp. All foetuses recorded in the present study were nearly fullterm and close to lengths-at-birth previously reported for the species (Barbarino \& Lasso, 2009; Garrone-Neto, 2010; Muñoz-Osorio \& Mejía-Falla, 2013). Therefore, it can be assumed that the values obtained in this study for the gill measurements of potamotrygonid embryos may be close to the averages for neonates. However, the comparisons should be made based on mass-specific area because that permits the comparison of species within the same weight range. This becomes especially important in freshwater stingrays of the family Potamotrygonidae. In the present study, the mass-specific gill area is inversely related to the body area of potamotrygonid embryos, with a slope of $b=$ 0.67 . Therefore, small rays have more gill surface area and thus more efficient gas exchange than larger animals. A common observation is that smaller fish are less sensitive to hypoxic environments (Chapman \& Mckenzie, 2009). This may explain why small fishes are present in high densities in oxygen-limited environments. An implicit model predicts a positive relationship between juvenile size and aquatic dissolved oxygen with respect to maternal fitness and predation pressure (Reardon \& Thibert-Plante, 2010). Hypoxic environments may act as refugia for potamotrygonid neonates and for other small prey fishes because their large piscine predators may be unable to tolerate hypoxic waters. Furthermore, potamotrygonid neonates may have an ecological advantage for preying on the small teleost fish that inhabit the same environment. The neonates of Plesiotrygon iwamae were an outlier in this study; this freshwater stingray has a very small massspecific gill area compared to its body size. This suggests that this species may be very hypoxia-sensitive. Adult animals exhibit a very sluggish mode of life, and after capture it was observed that excessive exercise would result in hypoxic stress.

The opening of the spiracle is related to the total gill area. In Plesiotrygon iwamae the spiracles are much reduced, whereas other potamotrygonids have well-developed spiracles that also admit water into the orobranchial chamber. However, the spiracle is a widely variable characteristic in elasmobranchs. Some of this variation may be closely related to life mode. In the case of Plesiotrygon, it is possible that a small opening of the spiracles may help to reduce the amount of suspended particles on the bottom when the ray swims in the main river channel. Typically, water enters through the mouth and spiracle and out through the gill slits (Summers \& Ferry-Graham, 2001). It is believed that spiracles are the major inspiratory opening in skates and rays (Crigg, 1970). However, the hedgehog skate (Leucoraja erinacea) exhibits two mode of ventilation: it can take in water either through the spiracles alone or by the combined action of the mouth and spiracles (Summers \& Ferry-Graham, 2001). In potamotrygonids, the relative opening of the spiracle has been used as an ecomorphological index of respiratory performance (Lonardoni et al., 2009). According to these authors, larger spiracle may be related to hypoxia tolerance, primarily due to low oxygen concentrations on the river bottom, which is a common feature in Amazonian water bodies. However, this relationship has not been demonstrated on the basis of functional morphology. In this study, it was demonstrated that total gill surface area increases with the relative opening of the spiracle in potamotrygonids. Thus, if Potamotrygon sp., P. motoro, and P. orbignyi have large spiracles and a large gill area, it suggests common morpho-physiological characteristics associated with oxygen availability, in same way as has been observed for several Amazonian electric knifefishes (genus Brachyhypopomus Mago-Leccia, 1994) that have unusually large gills enabling them to tolerate hypoxic or even anoxic waters (Crampton et al., 2008).

In conclusion, larger near-term embryos have a larger gill surface area and larger spiracles. However, per unit of weight, smaller potamotrygonids (e.g., cururu ray Potamotrygon sp. exhibited a higher mass-specific gill area than larger potamotrygonids (for example, Paratrygon aiereba). The higher mass-relative gill area observed in 
near-term embryos may be advantageous because the neonate can use hypoxic environments that may serve as refugia against predators and also can prey on the small teleost fishes that explore the same environment. Based on gill morphometry, it was observed that Potamotrygon motoro and Potamotrygon orbignyi are active species; Potamotrygon sp. has an intermediate lifestyle, whereas Paratrygon and Plesiotrygon are sluggish rays.

\section{Acknowledgments}

This research was supported by grants from the Fundação de Amparo à Pesquisa do Estado do Amazonas (FAPEAMPPP \#389/2012 and FAPEAM-UNIVERSAL \#209/2012) to Wallice P. Duncan. Marisa N. Fernandes is the recipient of a research fellowship from $\mathrm{CNPq}$, and Maria I. Silva was recipient of an undergraduate fellowship from Science without Borders Scholarship Program/CNPq.

\section{References}

Almeida, M. P., P. M. O. Lins, P. Charvet-Almeida \& R. B. Barthem. 2010. Diet of the freshwater stingray Potamotrygon motoro (Chondrichthyes: Potamotrygonidae) on Marajó Island (Pará, Brazil). Brazilian Journal of Biology, 70: 155-162.

Almeida-Val, V. M. F., A. L. Val \& I. Walker. 1999. Long- and short-term adaptation of Amazon fishes to varying $\mathrm{O}_{2}$-levels: intra-specific phenotypic plasticity and interspecific variation. Pp. 185-203. In: Val, A. L. \& V. M. F. Almeida-Val (Eds.). Biology of tropical fishes. Manaus, Amazonas, INPA.

Barbarino, A. \& C. A. Lasso. 2009. La pesca comercial de la raya Manta Paratrygon aiereba (Müller \& Henle, 1841) (Myliobatiformes, Potamotrygonidae), En el Rio Apure, Venezuela. Acta Apuroquia, 1: 24-31.

Chapman, L. J. \& D. McKenzie. 2009. Behavioural responses and ecological consequences. Pp. 26-77. In: Richards, J. G., A. P. Farrell \& C. J. Brauner (Eds.). Hypoxia in fishes. San Diego, CA, Elsevier.

Charvet-Almeida, P., M. L. G. Araújo \& M. P. Almeida. 2005. Reproductive aspects of freshwater stingrays (Chondrichthyes: Potamotrygonidae) in the Brazilian Amazon Basin. Journal of Northwest Atlantic Fishery Science, 34: 165-171.

Costa, O. T. F., A. C. E. Pedretti, A. Schmitz, S. F. Perry \& M. N. Fernandes. 2007. Stereological estimation of surface area and barrier thickness of fish gills in vertical sections. Journal of Microscopy, 225: 1-9.

Crampton, W. G. R., L. J. Chapman \& J. Bell. 2008. Interspecific variation in gill size is correlated to ambient dissolved oxygen in the Amazonian electric fish Brachyhypopomus (Gymnotiformes: Hypopomidae). Environmental Biology of Fish, 83: 223-235.

Crigg, G. C. 1970. Use of the first gill slits for water intake in a shark. Journal Experimental Biology, 52: 569-574.

Cruz, A. L., M. N. Fernandes \& S. F. Perry. 2009. Effect of histological processing and methacrylate sectioning on the area of gill tissue in teleost. Brazilian Journal of Biology, 69: 385-387.

De Jager, S. \& W. J. Dekkers. 1975. Relation between gill structure and activity in fish. Netherlands Journal of Zoology, 25: 276-308.
Duncan, W. P., O. T. F. Costa, M. L. G. Araujo \& M. N. Fernandes. 2009. Ionic regulation and $\mathrm{Na}^{+}-\mathrm{K}^{+}$-ATPase activity in gills and kidney of the freshwater stingray Paratrygon aiereba living in white and blackwaters in the Amazon Basin. Journal of Fish Biology, 74: 956-960.

Duncan, W. P., O. T. F. Costa, M. M. Sakuragui \& M. N. Fernandes. 2010. Functional morphology of the gill in Amazonian freshwater stingrays (Chondrichthyes: Potamotrygonidae): implications for adaptation to freshwater. Physiological and Biochemical Zoology, 83: 19-32.

Duncan, W. P. \& M. N. Fernandes. 2010. Physicochemical characterization of the white, black, and clearwater rivers of the Amazon Basin during the rainy period and its implications on the distribution of freshwater stingrays (Chondrichthyes, Potamotrygonidae). Pan-American Journal of Aquatic Sciences, 53: 454-464.

Duncan, W.P., N. F. Silva \& M. N. Fernandes. 2011. Mitochondrionrich cellsdistribution, $\mathrm{Na}+/ \mathrm{K}+$-ATPase activity and gill morphometry of the Amazonian freshwater stingrays (Chondrichthyes: Potamotrygonidae). Fish Physiology and Biochemistry, 37: 523-531.

Emery, S. H. \& A. Szczepanski. 1986. Gill dimensions in pelagic elasmobranch fishes. Biology Bulletin, 171: 441-449.

Fernandes M. N., S. E. Moron \& M. M. Sakuragui. 2007. Gill morphological adjustments to environment and the gas exchange function. Pp. 93-120. In: Fernandes, M. N., F. T. Rantin, M. L. Glass \& B. G. Kapoor (Eds.). Fish respiration and environment. Enfield, Science Publishers.

Garrone-Neto, D. 2010. Considerações sobre a reprodução de duas espécies de potamotrigonídeos (Myliobatiformes, Potamotrygonidae) na região do Alto Rio Paraná, Sudeste do Brasil. Pan-American Journal of Aquatic Sciences, 5: 101-111.

Garrone-Neto, D. \& I. Sazima. 2009a. Stirring, charging, and picking: hunting tactics of potamotrygonid rays in the upper Paraná River. Neotropical Ichthyology, 7: 113-116.

Garrone-Neto, D. \& I. Sazima. 2009b. The more stirring the better: cichlid fishes associate with foraging potamotrygonid rays. Neotropical Ichthyology, 7: 499-501.

Garrone-Neto, D. \& V. S. Uieda. 2012. Activity and habitat use of two species of stingrays (Myliobatiformes: Potamotrygonidae) in the upper Paraná River basin, Southeastern Brazil. Neotropical Ichthyology, 10: 81-88.

Gray, I. E. 1954. Comparative study of the gill area of marine fishes. Biological Bulletin, 107: 219-225.

Hopwood, D. 1967. Some aspects of fixation with glutaraldehyde. A biochemical and histochemical comparison of the effects of formaldehyde and glutaraldehyde fixation on various enzymes and glycogen, with a note on penetration of glutaraldehyde into liver. Journal of Anatomy, 101: 83-92.

Hughes, G. M. 1970. Morphological measurements on the gills of fishes in relation to their respiratory function. Folia Morphologica, 18: 78-95.

Hughes, G. M. 1984. General anatomy of the gills. Pp. 1-72. In: Hoar, W. S. \& D. J. Randall (Eds.). Fish physiology. Orlando, FL, Academic Press. v. 10.

Hughes, G. M. \& M. Morgan. 1973. The structure of fish gills in relation to their respiratory function. Biological Reviews, 48: 419-475.

Hughes, G. M., S. F. Perry \& J. Piiper. 1986. Morphometry of the gills of the elasmobranch Scyliorhinus stellaris in relation to body size. Journal Experimental Biology, 121: 27-42. 
Hughes, G. M. \& D. E. Wright. 1970. A comparative study of the ultrastructure of the water-blood pathway in the secondary lamellae of teleost and elasmobranch fishes - benthic forms. Zeitschrift für Zellforschung und mikroskopische Anatomie, 104: 478-493.

Karakatsouli, N., K. Tanaris, C. Balaskas \& S. E. Papoutsoglou. 2006. Gill area and dimensions of gilthead sea bream. Journal of Fish Biology, 69: 291-299.

Lonardoni, A. P., E. D. Oliveira \& E. Goulart. 2009. Trophic ecomorphology of Potamotrygon falkneri and Potamotrygon motoro (Chondrichthyes - Potamotrygonidae) on the upper Paraná river floodplain, Brazil. Pan American Journal of Aquatic Sciences, 4: 436-445.

Moro, G., P. Charvet \& R. S. Rosa. 2012. Insectivory in Potamotrygon signata (Chondrichthyes: Potamotrygonidae), an endemic freshwater stingray from the Parnaíba River basin, northeastern Brazil. Brazilian Journal of Biology, 72: 885-891.

Muñoz-Osorio, L. A. \& P. A. Mejía-Falla. 2013. Primer registro de la raya manzana, Paratrygon aiereba (Müller \& Henle, 1841) (Batoidea: Potamotrygonidae) para el río Bita, Orinoquía, Colombia. Latin America Journal of Aquatic Research, 41: 189-193.

Perry, S. F. 1990. Recent advances and trends in the comparative morphometry of vertebrate gas exchange organs. Pp. 4371. In: Boutilier, R. G. (Ed.). Advances in comparative and environmental physiology. New York, Springer-Verlag. v. 6: Vertebrate gas: exchange from environment to cell.

Reardon, E. E. \& X. Thibert-Plant . 2010. Optimal offspring size influenced by the interaction between dissolved oxygen and predation pressure. Evolutionary Ecology Research, 12: 377-387.

Rosa, R. S. 1985. A systematic revision of the South American freshwater stingrays (Chondrichthyes: Potamotrygonidae). Unpublished Ph.D. Dissertation, The College of William and Mary, $523 \mathrm{p}$.

Rosa, R. S., P. Charvet-Almeida \& C. C. D. Quijada. 2010. Biology of the South American Potamotrygonid Stingrays. Pp. 241-286. In: Carrier, J.C., J. A. Musick \& M. R. Heithaus (Eds.). Sharks and their relatives II: biodiversity, adaptive physiology, and conservation. $1^{\text {st }}$ ed. Boca Ranton, USA, CRC Press. Marine Biology Series, 11.
Sakuragui, M. M., J. R. Sanches \& M. N. Fernandes. 2003. Gill chloride cell proliferation and respiratory responses to hypoxia of the Neotropical erythrinid fish Hoplias malabaricus. Journal of Comparative Physiology B, 173: 309-317.

Schwartz, F. J., C. R. Saleeby, Jr \& G. S. Rose II. 1993. Body surface areas and gill filaments in two carcharhinid sharks captured off North Carolina. The Journal of the Elisha Mitchell Scientific Society, 109: 55-61.

Shibuya, A., J. Zuanon \& S. Tanaka. 2012. Feeding behavior of the Neotropical freshwater stingray Potamotrygon motoro (Elasmobranchii: Potamotrygonidae). Neotropical Ichthyology, 10: 189-196.

Summers, A. P. \& L. A. Ferry-Graham. 2001. Respiratory modes and mechanics of the hedgehog skate (Leucoraja erinacea) testing the continuous flow model. Journal of Experimental Biology, 204: 1577-1587.

Wegner, N. C., C. A. Sepulveda, K. B. Bull \& J. B. Graham. 2010. Gill morphometrics in relation to gas transfer and ram ventilation in high-energy demand teleosts: Scombrids and Billfishes. Journal of Morphology, 271: 36-49.

Wells, P. R. \& A. W. Pinder. 1996. The respiratory development of Atlantic salmon I. Morphometry of gills, yolk sac and body surface. Journal Experimental Biology, 199: 2725-2736.

Wood, C. M., A. Y. O. Matsuo, R. J. Gonzalez, R. W. Wilson, M. L. Patrick \& A. L. Val. 2002. Mechanisms of ion transport in Potamotrygon, a stenohaline freshwater elasmobranch native to the ion-poor blackwaters of the Rio Negro. Journal of Experimental Biology, 205: 3039-3054.

Submitted September 7, 2014 Accepted November 13, 2014 by Bernardo Baldisserotto Published March 31, 2015 
